\title{
Analysis of abnormal expansion of pipe system and optimization of structural stress in $350 \mathrm{MW}$ unit
}

\author{
Xin $\mathrm{LIU}^{1}{ }^{*}$, Yanming ZHANG ${ }^{1}$, Qun $\mathrm{LIU}^{1}, \mathrm{Xu} \mathrm{SUN}^{1}, \mathrm{Yu} \mathrm{WANG}^{2}$, and Liye ZHAO ${ }^{3}$ \\ ${ }^{1}$ Datang Northeast Electric Power Test \& Research Institute, China \\ ${ }^{2}$ Datang Suihua Thermal Power Co., Ltd., China \\ ${ }^{3}$ Northeast Electric Power Design Institute Co., Ltd, of China Power Engineering Consulting Group, China
}

\begin{abstract}
A 350MW power plant main steam and reheat hot steam pipe subsidence occurred in part of the pipe section, through field inspection, calculation and checking analysis, combined with pipeline support and hanger adjustment, load testing and elevation measurement and other means, the settlement of the pipe system to optimize the overall stress state of the pipe system. Through the thermal displacement of the pipe system support lifting point, the selection and calculation of the pipe system support hanger and the overall design state stress check of the pipe system, the design state is basically consistent with the check state. Through to the key node load tests have shown that small spring hanger selection is the primary cause of section settling, combined with the spring adjustment space and calculation results are part of the hanger. Finally, the settlement of pipeline is realized, main steam pipe at the same time a stress and secondary stress were achieved about $15 \%$ of the decline, piping stress has been further optimized.
\end{abstract}

\section{Background}

With the continuous development of the electric power industry, the design and construction cycle of thermal power units is shortened, leading to frequent accidents in the soda pipeline [1]. Flexible transformation of units continues to deepen, which is mainly to solve the problem of stable operation of coal-fired units [2]. Considering from the aspect of pipeline displacement and expansion, depth peak adjustment is bound to have a great impact on pipeline expansion. Steam water pipeline in thermal power plant is an important part of the transmission of steam water medium [3], and its safety state directly affects the stable operation of the unit. Especially after the new unit is put into operation, the space position of the power pipeline should be as close as possible to the designed cold line and hot line. Any large linear deviation may bring serious consequences [4]. Combined with the abnormal pipe displacement in a power plant, the settlement causes were analyzed and investigated, and comprehensive treatment of pipe system and stress optimization were carried out.

\section{Introduction}

The capacity of Unit 1 in a power plant is $350 \mathrm{MW}$. The boiler is a supercritical variable pressure running direct current boiler with single furnace, one reheat, balanced ventilation, built-in starting system without starting circulating pump, boiler running layer, long rod ash blower platform is a large platform with grid plate, tight and closed, dry slag discharging, full steel frame, full suspension structure $\Pi$ boiler. Unit 1 has operated for about 11,000 hours since it was put into operation in December 2017. The main steam pipe material is SA335P91, the design specification is $\$ 356 \times 60 \mathrm{~mm}$, the design temperature is $576^{\circ} \mathrm{C}$, the design pressure is $25.4 \mathrm{MPa}$. The material of the steam pipe in the reheating section is SA335-P91, the design specification is $\Phi 559 \times 30 \mathrm{~mm}$, the design temperature is $576^{\circ} \mathrm{C}$, and the design pressure is $4.43 \mathrm{MPa}$. The pressure, temperature, and flow rate of the main steam and reheat steam are matched with the parameters of the steam turbine, and the maximum continuous evaporation rate is BMCR1110t/h, which ultimately matches the VWO condition of the steam turbine.

\section{Problem introduction}

During the routine inspection of the unit, maintenance personnel found that the cold state value of all dampers was larger than the designed value during the adjustment of dampers on the top position of the main steam pipeline and the reheating hot section of the steam pipeline, and the connecting bolts had been put to the maximum. According to this situation, it is suspected that the abnormal settlement occurred in the pipe section. It is necessary to measure the elevation of the main steam pipe and part of the steam pipe in the reheating hot section in cold state. At the same time, the spring deformation was recorded by visual measurement, and some of the cold compression values of the spring were deviated from the design.

\footnotetext{
* Corresponding author: Xin Liu 1207298862@qq.com 


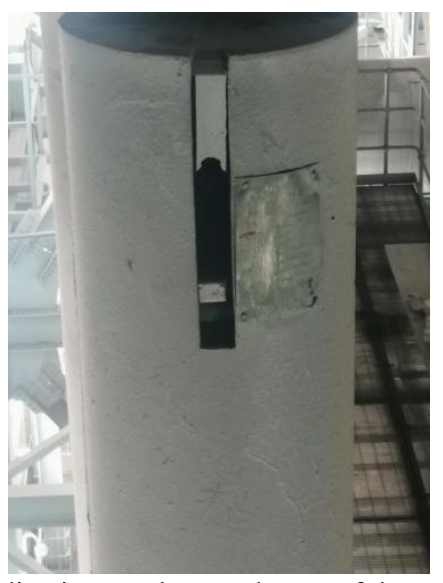

Figure 1 Indicating an abnormal state of the spring hanger

\section{Comprehensive management of settlement}

Carry out plan discussion for problems found in power plant. First of all, the cold state of the pipeline to remove insulation pipeline elevation check. Secondly, some spring hanger and constant force spring hanger are tested to test the actual load state of the hanger. Finally, the final adjustment plan is finalized according to the test results.

\subsection{Stress check design condition}

Perform modeling and joint calculation for the main steam pipeline and the reheating cold section steam pipeline. The reference drawing numbers are FA03981S-J0902-002, FA03981S-J0904-002, FA03981S-J0905-003. The establishment of the physical model is shown in Figure 2 and Figure 3.

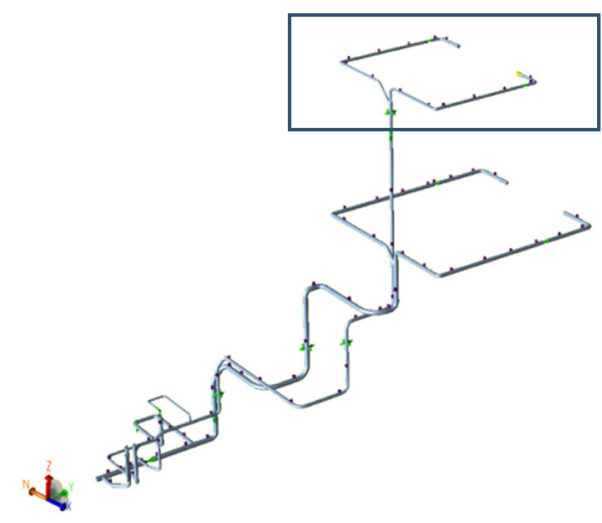

Figure 2 Pipeline joint calculation model

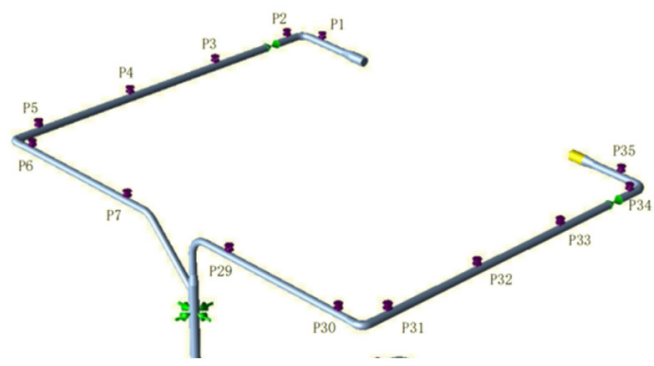

Figure 3 Main steam stove top piping model diagram

\subsubsection{Thermal displacement calculation of piping support points}

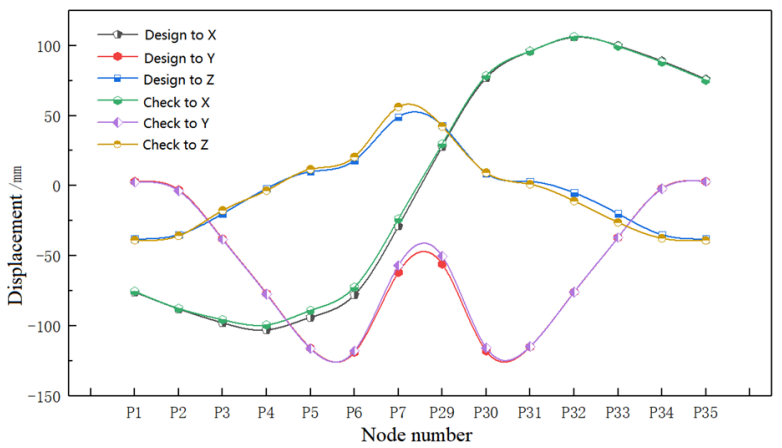

Figure 4 Comparison of pipeline thermal displacement data between design state and check state

Physical modeling according to the design drawings, the calculated check point pipe support thermal displacement state, and the results were compared with the Institute. Since the state check calculated using software and pipe stress state is calculated using different software design, design and check state calcd Calcd not identical state is normal. According to the check calculation result of the design drawing, as shown in Fig. 4, the overall thermal displacement of the checked state pipe system is consistent with the calculated value of the design state.

\subsubsection{Calculation of working load and hanger selection}

Similarly, according to the design drawings, the calculated working load and type of the checked support and hanger are compared with those of the designed support and hanger, and the results are shown in Table 1.

Table 1 Comparison of design state and check state working load and support type

\begin{tabular}{|c|c|c|c|c|}
\hline \multirow[b]{2}{*}{$\begin{array}{l}\text { No. of } \\
\text { supports } \\
\text { and } \\
\text { hangers }\end{array}$} & \multicolumn{2}{|c|}{ Design state } & \multicolumn{2}{|c|}{ Check state } \\
\hline & $\begin{array}{l}\text { Types of } \\
\text { supports } \\
\text { and } \\
\text { hangers }\end{array}$ & $\begin{array}{l}\text { Working } \\
\text { load/N }\end{array}$ & $\begin{array}{l}\text { Types of } \\
\text { supports } \\
\text { and } \\
\text { hangers }\end{array}$ & $\begin{array}{l}\text { Working } \\
\text { load/N }\end{array}$ \\
\hline $\begin{array}{c}\text { P1 } \\
(550)\end{array}$ & $\begin{array}{l}\text { Single } \\
\text { spring } \\
\text { hanger }\end{array}$ & 8591 & $\begin{array}{l}\text { Spring } \\
\text { hanger }\end{array}$ & 9173 \\
\hline $\begin{array}{c}\text { P2 } \\
(530)\end{array}$ & $\begin{array}{l}\text { Single } \\
\text { spring } \\
\text { hanger }\end{array}$ & 25604 & $\begin{array}{l}\text { Spring } \\
\text { hanger }\end{array}$ & 26778 \\
\hline $\begin{array}{c}\text { P3 } \\
(470)\end{array}$ & $\begin{array}{l}\text { Single } \\
\text { spring } \\
\text { hanger }\end{array}$ & 32142 & $\begin{array}{l}\text { Spring } \\
\text { hanger }\end{array}$ & 30591 \\
\hline $\begin{array}{c}\text { P4 } \\
(420)\end{array}$ & $\begin{array}{l}\text { Single } \\
\text { spring } \\
\text { hanger }\end{array}$ & 38554 & $\begin{array}{l}\text { Spring } \\
\text { hanger }\end{array}$ & 32480 \\
\hline $\begin{array}{c}\text { P5 } \\
(390)\end{array}$ & $\begin{array}{l}\text { Single } \\
\text { spring } \\
\text { hanger }\end{array}$ & 17791 & $\begin{array}{l}\text { Spring } \\
\text { hanger }\end{array}$ & 17468 \\
\hline $\begin{array}{c}\text { P6 } \\
(350)\end{array}$ & $\begin{array}{l}\text { Single } \\
\text { spring } \\
\text { hanger }\end{array}$ & 19332 & $\begin{array}{l}\text { Spring } \\
\text { hanger }\end{array}$ & 20578 \\
\hline $\begin{array}{c}\text { P7 } \\
(340)\end{array}$ & $\begin{array}{c}\text { Single } \\
\text { constant }\end{array}$ & 27224 & $\begin{array}{c}\text { Single } \\
\text { constant }\end{array}$ & 26462 \\
\hline
\end{tabular}




\begin{tabular}{|c|c|c|c|c|}
\hline & $\begin{array}{c}\text { spring } \\
\text { hanger }\end{array}$ & spring & \\
\hline $\begin{array}{c}\text { P29 } \\
\text { hanger }\end{array}$ & $\begin{array}{c}\text { Single } \\
\text { spring } \\
\text { hanger }\end{array}$ & 24121 & $\begin{array}{c}\text { Spring } \\
\text { hanger }\end{array}$ & 23741 \\
\hline $\begin{array}{c}\text { P30 } \\
(240)\end{array}$ & $\begin{array}{c}\text { Single } \\
\text { spring } \\
\text { hanger }\end{array}$ & 20203 & $\begin{array}{c}\text { Spring } \\
\text { hanger }\end{array}$ & 21013 \\
\hline $\begin{array}{c}\text { P31 } \\
(200)\end{array}$ & $\begin{array}{c}\text { Single } \\
\text { spring } \\
\text { hanger }\end{array}$ & 19331 & $\begin{array}{c}\text { Spring } \\
\text { hanger }\end{array}$ & 16793 \\
\hline $\begin{array}{c}\text { P32 } \\
(170)\end{array}$ & $\begin{array}{c}\text { Single } \\
\text { spring } \\
\text { hanger }\end{array}$ & 39158 & $\begin{array}{c}\text { Spring } \\
\text { hanger }\end{array}$ & 32681 \\
\hline $\begin{array}{c}\text { P33 } \\
(120)\end{array}$ & $\begin{array}{c}\text { Single } \\
\text { spring } \\
\text { hanger }\end{array}$ & 32063 & $\begin{array}{c}\text { Spring } \\
\text { hanger }\end{array}$ & 30539 \\
\hline $\begin{array}{c}\text { P34 } \\
(60)\end{array}$ & $\begin{array}{c}\text { Single } \\
\text { spring } \\
\text { hanger }\end{array}$ & 18782 & $\begin{array}{c}\text { Spring } \\
\text { hanger }\end{array}$ & 26783 \\
\hline $\begin{array}{c}\text { P35 } \\
(40)\end{array}$ & $\begin{array}{c}\text { Single } \\
\text { spring } \\
\text { hanger }\end{array}$ & 11159 & $\begin{array}{l}\text { Spring } \\
\text { hanger }\end{array}$ & 9102 \\
\hline
\end{tabular}

Through calculation and verification of the working load and type selection of the furnace top supports and hangers, it can be seen that the type of the checked supports and hangers is basically consistent with the type of the designed supports and hangers, but there is a large deviation between the working load and the design of individual hangers, such as $\mathrm{P} 4$ spring hanger. The checked load is about $0.6 \mathrm{kn}$ lower than the designed load, and the load deviation is about $15.7 \%$. The other working loads are basically consistent.

\subsubsection{Stress check of piping system in overall design state}

In order to facilitate engineering application, according to the principle of equivalent superposition of forces in mechanics, the pipeline stress is divided into primary stress and secondary stress. The primary stress includes the sum of internal pressure stress and other axial stress caused by continuous external load; the secondary stress is the range of thermal expansion stress due to thermal expansion and cold contraction and other displacement constraints.

The pipeline stress of the whole piping system is calculated, and the following primary stress and secondary stress are calculated, and the maximum primary stress accounts for $51.1 \%$ of the allowable stress, as shown in Figure 5, and the primary stress distribution of the piping system is shown in Figure 6. The maximum secondary stress accounts for $64.1 \%$ of the allowable stress, as shown in Figure 7, and the primary stress distribution of the piping system is shown in Figure 8. It shows that there is no over stress in the pipeline system under the design state, and the safe operation of the pipeline can be guaranteed.

The design state physical model of the pipe system was established, and the thermal displacement of supporting points was calculated. And the work load of the support and hanger and the overall design stress of the pipe system were checked. The results show that the selection of the checked support and hanger is basically consistent with that of the design institute, and the stress calculation results of different working conditions are all passed.

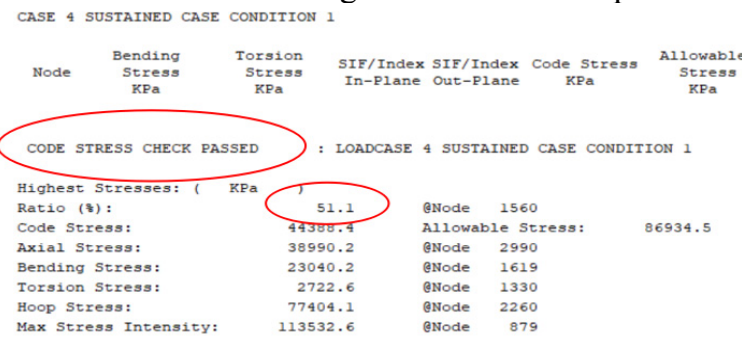

Figure 5 Calculation results of primary stress check for piping system

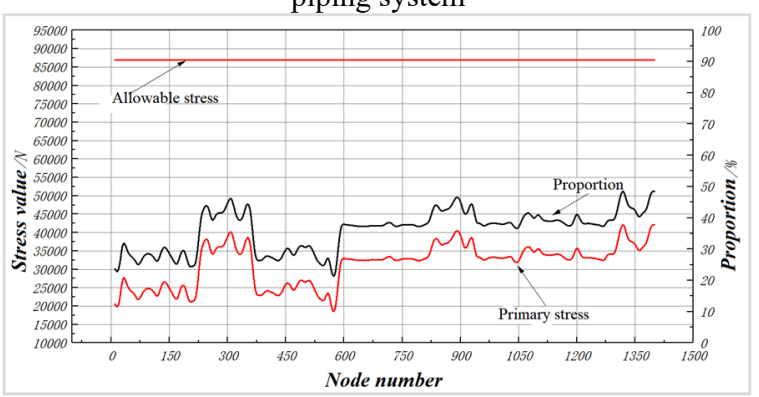

Figure 6 Primary stress distribution diagram of piping system

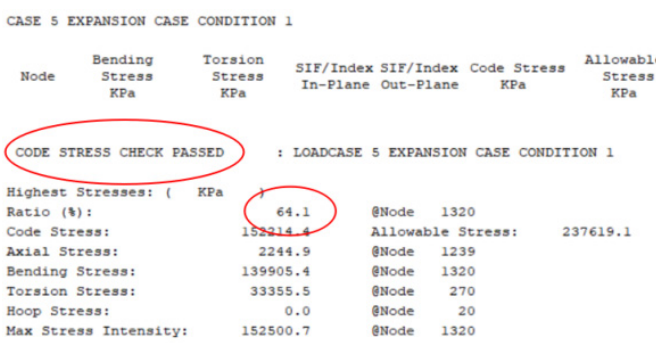

Figure 7 Calculation results of secondary stress check of

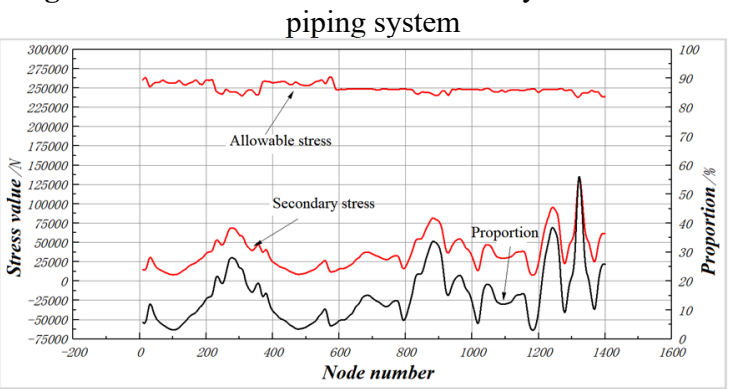

Figure 8 Secondary stress distribution diagram of piping system

\subsubsection{Pipeline elevation measurement and load test}

In this survey, load tester and elevation measuring level are selected to measure the load and elevation of specific measuring points. The positions of elevation measuring points of main steam pipe and reheat steam pipe are shown in Figure 9 and figure 10, and the measurement results are shown in Table 2 and table 3. 


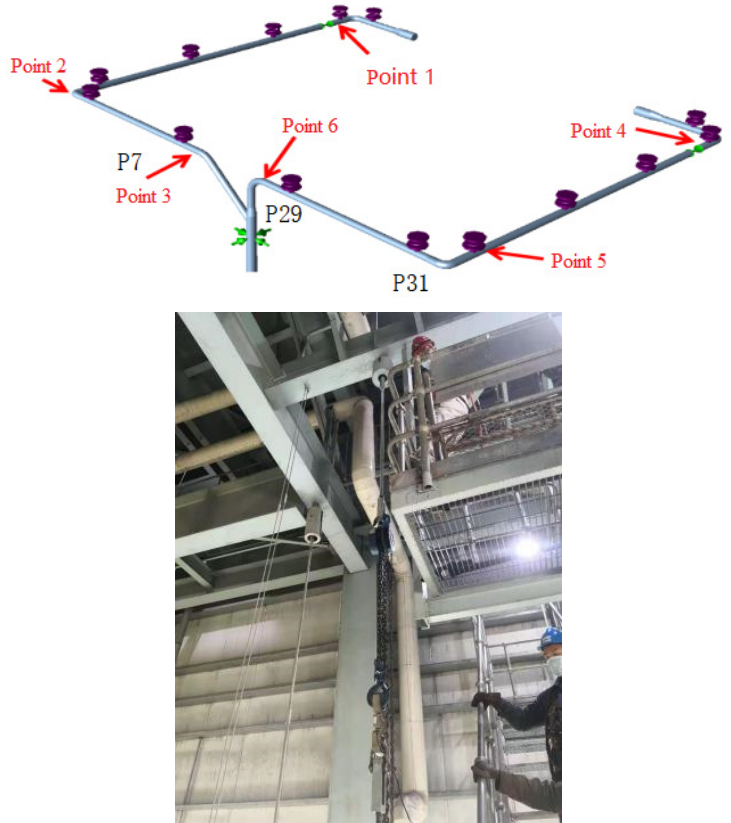

Figure 9 Schematic diagram of main steam pipe elevation measuring point location

Table 2 Measurement data statistics of elevation measurement points of main steam pipeline

\begin{tabular}{|c|c|c|c|c|}
\hline \multirow{4}{*}{$\begin{array}{l}\text { Main } \\
\text { steam } \\
\text { pipe on } \\
\text { the left } \\
\text { of the } \\
\text { furnace }\end{array}$} & $\begin{array}{c}\text { The } \\
\text { location of } \\
\text { the } \\
\text { measuring } \\
\text { point }\end{array}$ & $\begin{array}{c}\text { Actual } \\
\text { measured } \\
\text { elevation } / \mathrm{mm}\end{array}$ & $\begin{array}{c}\text { Design } \\
\text { elevation } / \mathrm{mm}\end{array}$ & $\begin{array}{c}\text { Pipe } \\
\text { diameter } \\
\text { size } / \mathrm{mm}\end{array}$ \\
\hline & $\begin{array}{l}\text { 1.Blocking } \\
\text { valve on } \\
\text { the back } \\
\text { side of the } \\
\text { furnace }\end{array}$ & 66679 & 66657 & $\Phi 356 \times 60$ \\
\hline & $\begin{array}{l}\text { 2.The } \\
\text { neutral side } \\
\text { of the } \\
\text { elbow on } \\
\text { the front } \\
\text { side of the } \\
\text { furnace }\end{array}$ & 66466 & 66485 & $\Phi 356 \times 60$ \\
\hline & $\begin{array}{c}\text { 3. The right } \\
\text { side of P7 } \\
\text { hanger }\end{array}$ & 66367 & 66394 & $\Phi 356 \times 60$ \\
\hline \multirow{3}{*}{$\begin{array}{l}\text { Main } \\
\text { steam } \\
\text { pipe on } \\
\text { the } \\
\text { right of } \\
\text { the } \\
\text { furnace }\end{array}$} & $\begin{array}{l}\text { 4.Blocking } \\
\text { valve on } \\
\text { the back } \\
\text { side of the } \\
\text { furnace }\end{array}$ & 66648 & 66646 & $\Phi 356 \times 60$ \\
\hline & $\begin{array}{l}5 . \text { On the } \\
\text { front side } \\
\text { of P31 } \\
\text { hanger }\end{array}$ & 66472 & 66499 & $\Phi 356 \times 60$ \\
\hline & $\begin{array}{l}\text { 6.The left } \\
\text { side of the } \\
\text { P29 hanger }\end{array}$ & 66354 & 66385 & $\Phi 356 \times 60$ \\
\hline
\end{tabular}

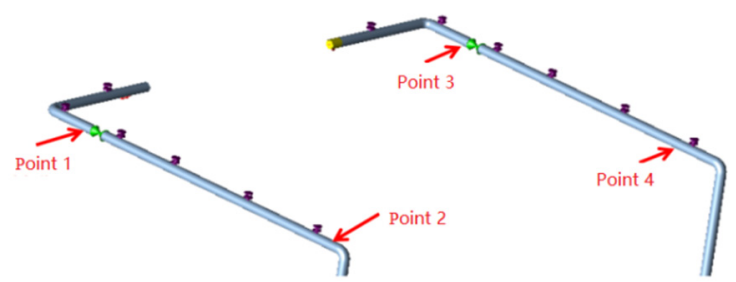

Figure 10 The position diagram of elevation measuring point of steam pipeline in reheated steam pipe
Table 3 Statistics of measurement data of elevation measurement points of steam pipeline in reheated steam pipe

\begin{tabular}{|c|c|c|c|c|}
\hline \multirow{3}{*}{$\begin{array}{l}\text { Steam } \\
\text { pipe of } \\
\text { the } \\
\text { reheat } \\
\text { section } \\
\text { on the } \\
\text { left } \\
\text { side of } \\
\text { the } \\
\text { furnace }\end{array}$} & $\begin{array}{c}\text { The } \\
\text { location of } \\
\text { the } \\
\text { measuring } \\
\text { point }\end{array}$ & $\begin{array}{c}\text { Actual } \\
\text { measured } \\
\text { elevation } / \mathrm{mm}\end{array}$ & $\begin{array}{c}\text { Design } \\
\text { elevation } / \mathrm{mm}\end{array}$ & $\begin{array}{c}\text { Pipe } \\
\text { diameter } \\
\text { size } / \mathrm{mm}\end{array}$ \\
\hline & $\begin{array}{l}\text { 1.Blocking } \\
\text { valve on } \\
\text { the back } \\
\text { side of the } \\
\text { furnace }\end{array}$ & 66623 & 66623 & $\Phi 559 \times 30$ \\
\hline & $\begin{array}{c}\text { 2.The } \\
\text { neutral side } \\
\text { of the } \\
\text { elbow on } \\
\text { the front } \\
\text { side of the } \\
\text { furnace }\end{array}$ & 66384 & 666379 & $\Phi 559 \times 30$ \\
\hline $\begin{array}{l}\text { Steam } \\
\text { pipe of } \\
\text { the } \\
\text { reheat } \\
\text { section }\end{array}$ & $\begin{array}{l}\text { 3. Blocking } \\
\text { valve on } \\
\text { the back } \\
\text { side of the } \\
\text { furnace }\end{array}$ & 66660 & 66623 & $\Phi 559 \times 30$ \\
\hline $\begin{array}{l}\text { right } \\
\text { side of } \\
\text { the } \\
\text { furnace }\end{array}$ & $\begin{array}{l}\text { 4.Location } \\
\text { of P23 } \\
\text { hanger }\end{array}$ & 66419 & 66403 & $\Phi 559 \times 30$ \\
\hline
\end{tabular}

The elevation measurement result is that the actual slope of measuring point 1 and measuring point 2 of the main steam pipe on the left side of the furnace is $213 \mathrm{~mm}$, and the calculated slope of the drawing design is $193.23 \mathrm{~mm}$, with a deviation of $10.36 \%$ 。 The actual slope of measurement point 2 and measurement point 3 is $99 \mathrm{~mm}$, and the calculated slope of the drawing design is $89.78 \mathrm{~mm}$, with a deviation of $10.27 \%$. The actual slope of measurement point 4 and measurement point 5 of the right main steam pipe of the furnace is $176 \mathrm{~mm}$, and the calculated slope of the drawing design is $176 \mathrm{~mm}$, without deviation. The actual slope of measurement point 5 and measurement point 6 is $118 \mathrm{~mm}$, and the calculated slope of the drawing design is $109 \mathrm{~mm}$, with a deviation of $8.26 \%$.

The actual slope of measuring point 1 and measuring point 2 of the steam pipe in the reheat section is $239 \mathrm{~mm}$, and the calculated slope of the drawing design is $232 \mathrm{~mm}$, which is basically the same. The actual slope of measurement point 3 and measurement point 4 is $241 \mathrm{~mm}$, and the calculated slope of the drawing design is $232 \mathrm{~mm}$, which is basically the same. Therefore, through the measurement and calculation of the pipeline elevation, it can be known that there is a certain deviation between the pipeline elevation and the design value in the cold state. In view of this situation, the corresponding measuring points are selected for the support and hanger load measurement, and the measurement positions are selected as shown in Figure 11 and Figure 12, The load measurement results are shown in Table 4 and Table 5. 


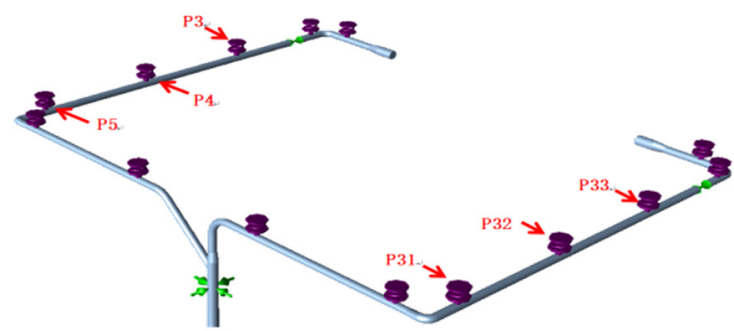

Figure 11 Schematic diagram of load measuring points for spring hanger of main steam pipe

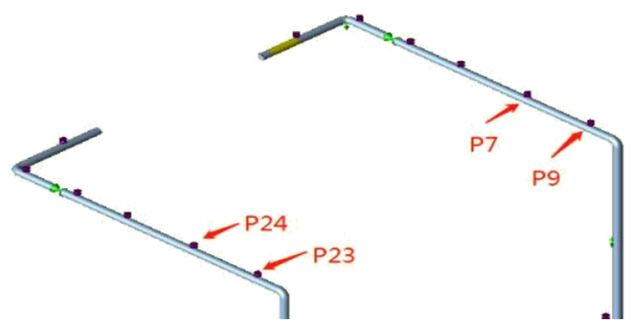

Figure 12 Location diagram of load measuring points for spring hanger of steam pipe in reheat hot section

Table 4 The measurement results of the load measurement point of the main steam pipeline

\begin{tabular}{|c|c|c|c|c|}
\hline $\begin{array}{c}\text { Number } \\
\text { of } \\
\text { hanger }\end{array}$ & $\begin{array}{c}\text { Type of } \\
\text { spring }\end{array}$ & $\begin{array}{c}\text { Measured } \\
\text { load/N }\end{array}$ & $\begin{array}{c}\text { Optimized } \\
\text { load for } \\
\text { cold } \\
\text { analysis/N }\end{array}$ & $\begin{array}{c}\text { Designed } \\
\text { work } \\
\text { load/N }\end{array}$ \\
\hline P4 & TD30B18 & 37100 & 41700 & 38554 \\
\hline P5 & TD30B16 & 23500 & 20277 & 17790 \\
\hline P31 & TD30B16 & 28300 & 21886 & 19331 \\
\hline P32 & TD30B18 & 38800 & 42337 & 39158 \\
\hline
\end{tabular}

Table 5 Measurement results of load measurement points of steam pipes in reheat section

\begin{tabular}{|c|c|c|c|c|}
\hline $\begin{array}{c}\text { Number } \\
\text { of } \\
\text { hanger }\end{array}$ & $\begin{array}{c}\text { Type of } \\
\text { spring }\end{array}$ & $\begin{array}{c}\text { Measured } \\
\text { load/N }\end{array}$ & $\begin{array}{c}\text { Optimi } \\
\text { zed } \\
\text { load for } \\
\text { cold } \\
\text { analysis } \\
/ \mathrm{N}\end{array}$ & $\begin{array}{c}\text { Design } \\
\text { ed } \\
\text { work } \\
\text { load/N }\end{array}$ \\
\hline P7 & TD120B19 & 46900 & 49586 & 40236 \\
\hline P9 & $\begin{array}{c}\text { LHE44- } \\
170 / 30204 S- \\
\text { M36 }\end{array}$ & 29100 & $/$ & 28491 \\
\hline P23 & $\begin{array}{c}\text { LHE42- } \\
180 / 25117 S- \\
\text { M36 }\end{array}$ & 22500 & $/$ & 22975 \\
\hline P24 & TD90B18 & 45400 & 47342 & 37819 \\
\hline
\end{tabular}

After measuring the actual cold load of the spring hanger at the measuring point, combined with the data of the elevation measurement, the amount of expansion and contraction of the spring hanger of the main steam pipe on the top of the furnace as shown in Table 6. The amount of expansion and contraction of the spring hanger of the steam pipe in the reheat section is adjusted as shown in Table 7.
Table 6 Comprehensive consideration of the adjustment of the supports and hangers on both sides of the main steam pipeline

\begin{tabular}{|c|c|c|c|}
\hline $\begin{array}{c}\text { Number } \\
\text { of } \\
\text { hanger }\end{array}$ & $\begin{array}{c}\text { Type of } \\
\text { spring }\end{array}$ & $\begin{array}{c}\text { The amount of } \\
\text { adjustment/mm }\end{array}$ & Remarks \\
\hline P3 & TD60B17 & $\begin{array}{c}\text { Tighten basket } \\
6 \mathrm{~mm}\end{array}$ & None \\
\hline P4 & TD30B18 & $\begin{array}{c}\text { Tighten basket } \\
7 \mathrm{~mm}\end{array}$ & None \\
\hline P5 & TD30B16 & No adjustion & None \\
\hline P31 & TD30B16 & No adjustion & None \\
\hline P32 & TD30B18 & $\begin{array}{c}\text { Tighten basket } \\
3 \mathrm{~mm}\end{array}$ & $\begin{array}{c}1 / 2 \text { of the } \\
\text { calculated } \\
\text { value }\end{array}$ \\
\hline P33 & TD60B17 & $\begin{array}{c}\text { Tighten basket } \\
\text { 4mm }\end{array}$ & $\begin{array}{c}1 / 2 \text { of the } \\
\text { calculated } \\
\text { value }\end{array}$ \\
\hline
\end{tabular}

Table 7 Comprehensive consideration of the adjustment of the supports and hangers on both sides of the reheated steam pipeline

\begin{tabular}{|c|c|c|c|}
\hline $\begin{array}{c}\text { Numb } \\
\text { er of } \\
\text { hanger }\end{array}$ & Type of spring & $\begin{array}{c}\text { The amount } \\
\text { of } \\
\text { adjustment } / \mathrm{m} \\
\mathrm{m}\end{array}$ & $\begin{array}{c}\text { Remark } \\
\mathrm{s}\end{array}$ \\
\hline P7 & TD120B19 & $\begin{array}{c}\text { Tighten } \\
\text { basket } 6 \mathrm{~mm}\end{array}$ & $\begin{array}{c}1 / 2 \text { of } \\
\text { the } \\
\text { calculat } \\
\text { ed value }\end{array}$ \\
\hline P9 & $\begin{array}{c}\text { LHE44-170/30204S- } \\
\text { M36 }\end{array}$ & No adjustion & None \\
\hline P23 & $\begin{array}{c}\text { LHE42-180/25117S- } \\
\text { M36 }\end{array}$ & No adjustion & None \\
\hline P24 & TD90B18 & $\begin{array}{c}\text { Tighten } \\
\text { basket 5mm }\end{array}$ & $\begin{array}{c}1 / 2 \text { of } \\
\text { the } \\
\text { calculat } \\
\text { ed value }\end{array}$ \\
\hline
\end{tabular}

\section{Optimal analysis of piping stress}

The final stress level of the pipeline system is optimized through the preliminary stress calculation of the pipeline and the determination of the support and hanger adjustment scheme, and the inspection and adjustment of the cold and hot state system of the pipeline support and hanger. Among them, the red line represents the stress applied to the promise, the black line represents the optimized node stress, and the blue line represents the percentage of the node stress in the allowable stress. See Figure 13-16 for details.

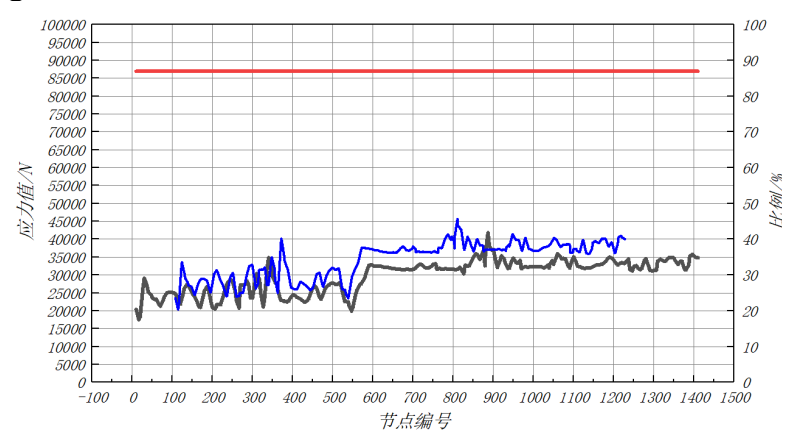

Figure 13 The primary stress of the main steam pipeline after optimization 


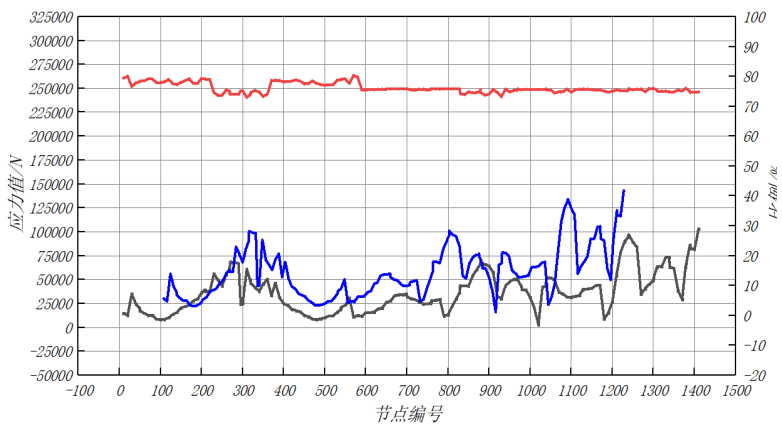

Figure 14 Secondary stress of the main steam pipe after optimization

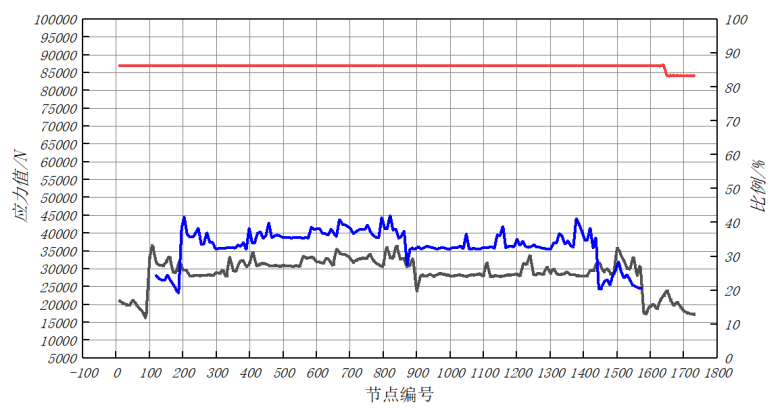

Figure 15 The primary stress of the reheated hot pipe after optimization

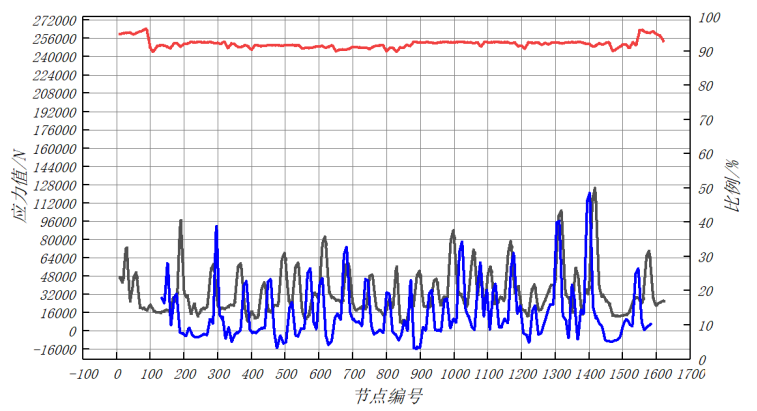

Figure 16 The secondary stress of the reheated hot section pipe after optimization

Through the system adjustment of the pipe support and hanger, the stress level of the main steam pipe and the reheated hot pipe is obviously optimized, and the stress level of piping system is stable. The proportion of primary stress to allowable stress in the main steam pipeline decreases from $51.1 \%$ before adjustment to less than $50 \%$ after adjustment, and the proportion of secondary stress to allowable stress decreases from $64.1 \%$ before adjustment to $49 \%$ after adjustment. The significant decrease of secondary stress improves the constrained stress state of pipeline and makes the expansion of pipeline more reasonable.

\section{Conclusion}

1.Through the thermal displacement of a $350 \mathrm{MW}$ pipe system support hoisting point, pipe system support hanger selection accounting and pipe system overall design state stress check, the design state and check state are basically consistent. Settling the reason is mainly because spring low in the working load selection, combined with the piping stress calculation, load test, section elevation test section settlement means to realize the control, and through the steam-water system adjustment, further optimize the structure of the piping stress, main steam a stress, secondary stress are a drop of $15 \%$ or more.

2.In the early stage of operation of the newly put into production unit, the support and hanger of the steamingwater pipe, especially the four major pipelines, should be checked as a whole and the stress should be checked. If necessary, the elevation measurement of some pipe sections and load test of sampling inspection should be carried out in combination with the inspection of support and hanger, so as to prevent the wrong selection of hanger due to the working load deviation in the design stage of support and hanger, which will have a great impact on the expansion of pipeline.

3.Strengthen the daily inspection and recording of pipeline supports and hangers, effectively grasp the pipeline displacement status, and discover pipeline settlement faults as soon as possible. Strengthen the quality control of the support and hanger installation to ensure that the materials, specifications and models of the support and hanger meet the design requirements; at the same time, strengthen the supervision, inspection, maintenance and adjustment of the support and hanger during operation[5].

\section{Reference}

1. G.K.He, M.Ming, R.Chen, etc. Analysis and treatment of main steam pipe sinking fault of 1000MW Ultra Supercritical Unit. Inner mongolia electric power, 037 (2) 39-43 (2019)

2. H.Cai, Z.G.Shi, C.P.Qin, etc. Analysis of the cracking reason of water wall pipe of deep peak regulating unit. Thermal power generation, 49(11)176-181 (2020)

3. M.Liu, Y.J.Guo, G.K.He, etc. Comprehensive evaluation and treatment of abnormal thermal expansion displacement of steam water pipeline in thermal power plant.Physical and chemical examination (Physics), 54(4)28-33 (2018)

4. J.M.Wang, L.H.Deng, X.J.Wu, etc. Analysis of linear deviation mechanism of low temperature reheater inlet pipe. Thermal power generation, 48(10)105-110 (2019)

5. Y.J.Guo. Failure analysis of in service pipe supports and hangers in thermal power plant. Thermal power generation, 37(2):84-86 (2008) 